\title{
UPAYA MENINGKATKAN HASIL BELAJAR IPS DENGAN MENGGUNAKAN METODE PEMBERIAN TUGAS DAN MEDIA KARTU TEBAK KATA PADA PESERTA DIDIK DI SDN 1 PULAU TELO KUALA KAPUAS TAHUN AJARAN 2016/2017
}

\author{
OLEH : Wayan Surti* M.Jailani**
}

\begin{abstract}
ABSTRAK
WAYAN SURTI: Upaya meningkatkan hasil belajar IPS dengan menggunakan metode pemberian tugas dan media tebak kata pada peserta didik di SDN 1 Pulau Telo Kuala Kapuas tahun ajaran 2016/2017. Skripsi. Palangkaraya: Fakultas Keguruan dan Ilmu Pendidikan Universitas Muhammadiyah Palangkaraya, 2017.

Penelitian ini bertujuan untuk 1) mengetahui aktivitas belajar IPS dengan menggunakan metode Pemberian tugas pada peserta didik kelas V SDN 1 Pulau Telo Kuala Kapuas tahun pelajaran 2016/2017, 2) mengetahui peningkatan hasil belajar IPS dengan menggunakan metode Pemberian Tugas pada peserta didik kelas V SDN 1 Pulau Telo Kuala Kapuas tahun pelajaran 2016/2017.

Metode penelitian yang digunakan dalam penelitian ini adalah Penelitian Tindakan Kelas (PTK). Subjek penelitian sebanyak 20 orang peserta didik terdiri dari 10 peserta didik laki-laki dan 10 peserta didik perempuan. Teknik pengumpulan data menggunakan observasi dan tes. Analisis data menggunakan analisis kualitatif dan kuantitatif.

Hasil penelitian menunjukan bahwa 1) Aktivitas belajar IPS dengan menggunakan metode Pemberian tugas pada peserta didik kelas V SDN 1 Pulau Telo Kuala Kapuas tahun pelajaran 2016/2017 baik. Aktivitas peserta didik pada siklus I yang menggunakan metode Pemberian Tugasrata-rata 3,0 cukup baik dan pada siklus II rata-rata 3,7 baik. 2) Ada peningkatan hasil belajar IPS dengan menggunakan metode Pemberian tugas pada peserta didik kelas VSDN 1 Pulau Telo Kuala Kapuas tahun pelajaran 2016/20/17. Hasil belajar IPS pada siklus I diperoleh rata-rata 63,25 dan ketuntasan $60 \%$ dan pada siklus II diperoleh rata-rata 70 dan ketuntasan $100 \%$.
\end{abstract}

Kata Kunci : Hasil Belajar, IPS , dan Metode Pemberian Tugas

\section{PENDAHULUAN}

Perkembangan zaman yang semakin maju pesat menuntut pula untuk dunia pendidikan yang harus terus berkembang menyesuaikan dengan zaman. Agar dapat merubah pola pikir guru, dari pola pikir yang masih awam dan kaku menjadi lebih modern. Hal tersebut sangat berpengaruh dalam kemajuan pendidikan di Indonesia. Menyikapi hal tersebut pakar-pakar pendidikan mengkritisi dengan cara mengungkapkan konsep dan teori pendidikan yang sebenarnya untuk mencapai tujuan pendidikan yang sesungguhnya.

Pendidikan adalah investasi jangka panjang yang memerlukan usaha dan dana yang cukup besar,hal ini diakui oleh semua 
orang atau suatu bangsa demi kelangsungan masa depannya,karena dari sinilah tunas muda harapan bangsa sebagai generasi penerus dibentuk. Pendidikan merupakan penggerak suatu Negara yang dapat mengarahkan ke arah yangjauh lebih baik. Oleh sebab itu, pendidikan sangat penting yang harus dimiliki oleh setiap manusia untuk mengembangkan dan membentuk watak serta peradapan bangsa yang bermanfaat.

Hal tersebut tercantum dalam Undang-Undang RI. No 20 Tahun 2003, tentang sistem Pendidikan Nasional bahwa :

Pendidikan adalah usaha sadar dan terencana untuk mewujudkan suasana belajar dan proses pembelajaran agar peserta didik secara aktif mengembangkan potensi dirinya untuk memiliki kekuatan spiritual keagamaan, pengendalian diri, kepribadian, kecerdasan, akhlak mulia, serta keterampilan yang diperlukan dirinya, masyarakat, bangsa dan Negara.

Pendidikan sebagai suatu bentuk kegiatan manusia dalam kehidupannya juga menempatkan tujuan sebagai sesuatu yang hendak dicapai, baik tujuan yang dirumuskan itu bersifat abstrak sampai pada rumusan-rumusan yang dibentuk secara khusus untuk memudahkan pencapaian tujuan yang lebih tinggi. Dalam UU No.2 Tahun 1989 dalam Hasbullah secara jelas disebutkan tujuan pendidikan nasional, menyatakan bahwa:

Mencerdaskan kehidupan bangsa dan mengembangkan manusia Indonesia seutuhnya, yaitu manusia yang beriman dan bertakwa kepada Tuhan Yang Maha Esa dan berbudi pekerti luhur, memiliki pengetahuan dan keterampilan, kesehatan jasmani dan rohani, kepribadian yang mantap dan mandiri serta rasa tanggung jawab kemasyarakatan dan kebangsaan.

Berbicara mengenai tujuan pendidikan nasional dalam hal ini kita akan mengaitkannya dengan tujuan pendidikan di sekolah dasar. Mungkin tujuannya tidak jauh berbeda, dalam pendidikan sekolah dasar juga memiliki tujuan untuk mencerdaskan peserta didik, hanya saja di sekolah dasar pendidikan yang diberikan berupa pendidikan-pendidikan dasar sebagai bekal mereka untuk masuk kependidikan dengan jenjang yang lebih tinggi.

Pendidikan harus dirasakan oleh semua orang. Pendidikan dapat berlangsung secara formal dan non formal. Pendidikan yang berlangsung disekolah dan peserta didik akan dididik oleh guru, sedangkan pendidikan yang berlangsung secara non formal yaitu berlangsung di luar sekolah. Pemerintah mengharuskan wajib belajar 9 tahun yaitu dari Sekolah Dasar (SD) hingga Sekolah Menengah Pertama (SMP).

Usia SD (6-12 tahun), merupakan usia dimana seorang anak masih senang bermain, dan sangat sulit untuk focus dalam memperhatikan pelajaran. Mereka cenderung tidak memperhatikan pembelajaran dan asik mengobrol sendiri dengan teman disebelahnya. Hal ini dikarenakan metode yang digunakan cenderung menoton.

Berdasarkan pengamatan pada saat proses pembelajaran IPS, diketahui bahwa kemampuan memahami pembelajaran peserta didik kelas V di SDN 1 Pulau Telo Kuala Kapuas Tahun Pelajaran 2016/2017 
masih rendah.Hal ini dapat dilihat ketika peserta didik diberi pertanyaan mengenai isi pelajaran, peserta didik tidak dapat menjawab dengan cepat, dan harus membuka kembali buku yang dibacanya tersebut. Sedangkan berdasarkan hasil tes , nilai rata-rata dari peserta didik yang berjumlah 20 adalah 60. Rata-rata tersebut masuk dalam kategori cukup. Ketuntasan belajar secara klasikal juga baru mencapai $30 \%$ karena hanya ada 8 peserta didik yang mencapai Kriteria Ketuntasan Minimal, yakni 60.

Rendahnya kemampuan siswa dalam mengikuti pembelajaran disebabkan oleh beberapa faktor, baik dari guru maupun dari peserta didik sendiri. Faktor-faktor tersebut misalnya, model dan metode pembelajaran yang dilakukan oleh guru masih konvensional, kurangnya motivasi peserta didik dalam mengikuti pembelajaran, dan guru tidak memberikan tugas pada akhir pembelajaran. Kemampuan peserta didik kelas V SDN 1 Pulau Telo Kuala Kapuas, perlu di tingkatkan dengan menerapkan metode pembelajaran yang baru dan berbeda dari pembelajaran sebelumnya, agar kemampuan peserta didik dapat Sebagai alternatif untuk mengoptimalkan kemampuan peserta didik dalam pembelajaran Ips, peneliti menggunakan metode pemberian tugas, dimana metode ini dilakukan saat akhir pelajaran,metode pemberian tugas diberikan bertujuan agar peserta didik mengulang kembali pelajaran yang telah dipelajari.

Bedasarkan permasalahan di atas dapat dilakukan Penelitian Tindakan Kelas dengan judul "Upaya Meningkatkan Hasil
Belajar IPS Dengan Menggunakan Metode Pemberian Tugas dan Media Kartu Tebak kata Pada Peserta Didik di SDN 1 Pulau Telo Kuala Kapuas Tahun Ajaran 2016/2017 “.

\section{TINJAUAN PUSTAKA}

\section{a. Pengertian Belajar}

Menurut Slameto (2003:34) "belajar adalah suatu proses perubahan tingkah laku sebagai interaksi dengan lingkungannya dalam memenuhi kebutuhan hidupnya atau belajar ialah suatu proses usaha yang dilakukan seseorang untuk memperoleh suatu perubahan tingkah laku yang baru secara keseluruhan, sebagai hasil pengalamannya sendiri dari interaksi dengan lingkungannya".

Dari uraian di atas dapat disimpulkan bahwa belajar merupakan suatu perubahan yang terjadi melalui latihan dan pengalaman dalam arti perubahan-perubahan yang disebabkan oleh pertumbuhan atau kematangan tidak dianngap sebagai hasil belajar seperti perubahan-perubahan yang terjadi pada diri seorang bayi.

\section{b. Pengertian Hasil Belajar}

Hasil belajar merupakan taraf keberhasilan peserta didik dalam mempelajari materi pelajaran di sekolah yang dinyatakan dalam bentuk skor perolehan hasil tes dari sejumlah materi pelajaran tertentu. Menurut Sudjana (2006:22) "Hasil belajar adalah kemampuan-kemampuan yang dimiliki peserta didik setelah ia menerima pengalaman belajar". Sedangkan menurut Oemar Hamalik (2006:30) bahwa "Hasil belajar adalah bila seseorang telah belajar 
akan terjadi perubahan tingkah laku pada orang tersebut, misalnya dari tidak tahu menjadi tahu, dari tidak mengerti menjadi mengerti". Adapun menurut Nasution (2004:57) mengemukakan bahwa :

Hasil belajar suatu perbuatan pada individu yang belajar, tidak hanya mengenai pengetahuan tetapi juga membentuk kecakapan dan penghayatan dalam diri pribadi individu yang belajar, atau hasil belajar yang diperoleh peserta didik yang telah mengikuti suatu materi tertentu dari mata pelajaran yang berupa data kuantitatif.

Berdasarkan uraian di atas bahwa hasil belajar merupakan kemampuankemampuan yang dimiliki peserta didik untuk menerima mata pelajaran yang belum tahu menjadi tahu, serta dalam diri pribadi yang belajar itu diperoleh dari hasil yang telah diikuti dalam suatu mata pelajaran yang berupa data kuantitatif dan kemampuan yang dimiliki peserta didik yang diperoleh dari hasil tes mengenai sejumlah pelajaran tertentu.

\section{c. Pengertian IPS}

\section{Arti Ilmu Pengetahuan Sosial}

Ilmu pengetahuan sosial merupakan salah satu mata pelajaran yang diberikan mulai dari SD/MI sampai SMP/MTs/SMPLB. IPS mengkaji seperangkat peristiwa, fakta, konsep, dan generalisasi yang berkaitan dengan ilmu sosial.

Wahab (2009:1) menyatakan bahwa "IPS merupakan bidang studi yang bahannya bersumber dari kehidupan manusia dimasyarakat, yang aspek-aspeknya meliputi sejarah, geografi, ekonomi, politik, sosiologi, antropologi, serta nilai-nilai". Sapriya ( 2009:7) menyatakan bahwa "Ilmu Pengetahuan Sosial merupakan salah satunama mata pelajaranyang diberikanpada jenjangpendidikan dasar danmenengah.Mata pelajaran IPSmerupakansebuahnama mata pelajaranyang diintegrasikandari mata pelajaran Sejarah, Geografi, danEkonomiserta mata pelajaran ilmu sosial lainnya.

\section{Tujuan IPS}

Mata pelajaran IPS merupakan program pengajaran yang bertujuan untuk mengembangkan potensi peserta didik agar peka terhadap masalah social yang terjadi dimasyarakat, memiliki sikap mental positif terhadap perbaikan segala ketimpangan yang terjadi, dan terampil mengatasi setiap masalah yang terjadi sehari-hari baik yang menimpa dirinya sendiri maupun yang menimpa masyarakat. Tujuan tersebut dapat dapat dicapai manakala program-program pelajaran IPS disekolah diorganisasikan secara baik.

Dalam Kurikulum Tingkat satuan Pendidikan (KTSP) 2006 tercantum bahwa tujuan IPS adalah :

a. Mengenal konsep-konsep yang berkaitan dengan kehidupan masyarakat dan lingkungannya.

b. Memiliki kemampuan dasar untuk berpikir logis dan kritis, rasa ingin tahu, inkuiri, memecahkan masalah, dan keterampilan dalam kehidupan social.

c. Memiliki komitmen dan kesadaran terhadap nilai-nilai social dan kemanusiaan. 
d. Memiliki kemampuan untuk berkomunikasi, bekerjasama dan berkompetisi dalam masyarakat yang majemuk, ditngkat local, nasional, dan global.

Sedangkan tujuan khusus pengajaran IPS disekolah dapat dikelompokkan menjadi empat komponen yaitu :

a. Memberikan kepada peserta didik pengetahuan tentang pengalaman manusia dalam kehidupan bermasyarakat pada masa lalu, sekarang dan masa akan datang.

b. Menolong peserta didik untuk mengembangkan keterampilan untuk mencari dan mengolah informasi.

c. Menolong peserta didik untuk mengembangkan nilai/sikap demokrasi dalam kehidupan bermasyarakat.

Menyediakan kesempatan kepada peserta didik untuk mengambil bagian/berperan serta dalam bermasyarakat.

\section{d. Media Pembelajaran}

\section{Pengertian Media}

Kata media berasal dari bahasa latin yang secara harfiah berarti : tengah, perantara, atau pengantar. Dalam bahasa arab media adalah perantara atau pengantar pesan dari pengirim kepada penerima pesan. Media merupakan semua bentuk perantara yang digunakan oleh manusia untuk menyampaikan atau menyebarkan ide, gagasan atau pendapat sehingga ide, gagasan atau pendapat yang dikemukakan itu sampai kepada penerima. Menurut Rodhatul Jennah, (2009:1) "Media adalah sarana untuk menyampaikan atau mengantarkan pesanpesan atau informasi yang bertujuan untuk proses pembelajaran". Sedangkan menurut Susilana dan Riyana (2007:5) menyatakan bahwa :

Media merupakan teknologi pembawa pesan yang dapat dimanfaatkan untuk keperluan pembelajaran atau sebagai sarana komunikasi dalam bentuk alat untuk memberikan perangsang bagi peserta didik supaya terjadi proses belajar, merangsang pikiran, perasaan, perhatian, dan kemauan peserta didik untuk belajar.

Berdasarkan uraian di atas bahwa media merupakan suatu alat perantara dan sebagai alat penyampai pesan dalam proses belajar mengajar agar efektif dan efisien.

\section{Fungsi Media Pembelajaran}

Menurut Jennah, (2009:19) menyatakan bahwa ada tiga fungsi media yang merupakan petunjuk mengapa media digunakan dan apa-apa saja yang dapat dilakukan oleh media, yaitu sebagai berikut :

a) Bersifat fiksatif, berarti media memiliki kemampuan untuk menangkap, menyimpan dan kemudian menampilkan kembali subjek atau kejadian.

b) Bersifat manipulatif, berarti menampilkan kembali objek atau kejadian dengan berbagai macam perubahan manipulasi sesuai keperluan.

c) Bersifat distributif, artinya menggunakan media dapat menjangkau sasaran yang lebih luas 
atau media mampu menjangkau peserta didik yang besar jumlahnya dalam satu kali penyajian secara serempak.

\section{Manfaat Media}

Menurut Jennah, (2009:22) manfaat media pembelajaran adalah sebagai berikut :

a) Penyampaian pelajaran menjadi lebih baku

b) Pembelajaran bisa lebih menarik

c) Pembelajaran menjadi lebih interaktif

d) Lama waktu pembelajaran yang diperlukan dapat dipersingkat.

e) Kualitas hasil belajar dapat ditingkatkan

f) Pembelajaran dapat diberikan kapan dan dimana diinginkan atau diperlukan.

g) Sikap positif peserta didik

h) Peran pembelajaran dapat berubah kearah yang lebih positif.

Sedangkan menurut Sudjana dan Rifai, (2002:21) manfaat media pembelajaran dalam proses belajar mengajar peserta didik antara lain :

a) Pembelajaran akan lebih menarik perhatian peserta didik sehingga dapat menumbuhkan motivasi belajar.

b) Bahan pembelajaran akan lebih jelas maknanya sehingga dapat lebih dipahami oleh peserta didik, dam memungkinkan peserta didik menguasai tujuan pembelajaran lebih baik. c) Metode mengajar akan lebih bervariasi, tidak semata-mata komunikasi verbal melalui penuturan kata-kata oleh guru, sehingga peserta didik tidak bosan dan guru tidak kehabisan tenaga, apalagi bila guru mengajar untuk setiap jam pelajaran.

d) Peserta didik banyak melakukan kegiatan belajar, dan juga aktivitas lain seperti mengamati, melakukan, mendemonstrasikan dan lain-lain.

\section{Pengertian Media Kartu Tebak Kata}

Tebak kata merupakan penyampaian materi ajar dengan menggunakan kata-kata singkat dalam bentuk kartu permainan sehingga peserta didik dapat menerima pesan pembelajaran melalui kartu itu. Tebakkata adalahpembelajaranyangdirancang dengancara menebak. Kartu tebakkataadalahmedia pembelajaran dalam bentukkartu yang ukurannyaseukuranpostcard atausekitar25 $\times$ $30 \mathrm{~cm}$ ".Dalam pembelajaran media kartu tebak kata terdapatkartu berisi soaldeskripsidan kartu berisijawabandari deskripsi tersebut.Pembelajaranmedia kartu tebak kata memungkinkansetiapsiswa dapat berpartisipasi aktifdalam pembelajaran.

\section{Metode Pemberian Tugas}

Menurut Fathurrohman dan Sutikno (2010:55), "metode mengajar adalah caracara menyajikan bahan pelajaran kepada peseerta didik untuk tercapainya tujuan yang telah ditetapkan". Sedangkan menurut Sudjana (2009:76) mengatakan bahwa : 
Metode mengajar adalah cara yang digunakan guru dalam mengadakan hubungan dengan peserta didik pada saat berlangsungnya pengajaran. Oleh karena itu, peranan metode mengajar sebagai sebagai alat bantu untuk menciptakan proses mengajar dan belajar. Dengan metode ini diharapkan tumbuh berbagai kegiatan belajar peserta didik sehubungan dengan kegiatan mengajar guru.

Berdasarkan pendapat di atas maka disimpulkan bahwa metode mengajar adalah suatu alat atau cara yang digunakan guru untuk menyajikan suatu pembelajaran menjadi efektif sehingga pembelajaran dapat berlangsung dengan baik dan tercapainya tujuan pembelajaran yang telah ditetapkan.

Metodepemberian tugas adalah metode penyajian bahan dimanaguru memberikan tugas tertentu agar siswamelakukankegiatan belajar". Tugas biasanyabisa dilaksanakan di rumah, di sekolah,di perpustakaan, dan ditempat lainnya. Tugasmerangsang anak untuk aktif belajar, baik secara individual maupun secarakelompok. Menurut Syaiful Sagala ( 2009:201 ) metode pemberian tugas adalah cara penyajian bahan pelajaran dimana guru memberikan tugas tertentu agar murid melakukan kegiatan belajar., kemudian harus dipertanggungjawabkannya. Tugas yang diberikan guru dapat memperdalam bahan pelajaran, dan dapat pula mengecek bahan bahan yang dipelajari. Tugas merangsang anak untuk aktif belajar baik secara individual atau kelompok
Bertitik tolak dari pendapat tersebut,makadapatdisimpulkan bahwametode pemberian tugasadalah suatu caramengajaryang digunakan untuk membimbingsiswamemecahkan persoalan dengan caramemberikan tugas kepadasiswa,yangdikerjakan didalam proses belajar mengajar di kelas. Tugas tersebut harus diselesaikan dan dikuasai siswadalam jangkawaktu tertentu, kemudian dipertanggung-jawabkan kepadaguruyangbersangkutan

Semua guru harus menyadari bahwasemua metodemengajaryangada, saling menyempurnakanantarayangsatu denganyanglainnya. Karenatidak ada satupun metodeyangsempurnatetapi adatitik kelemahannya. Oleh karenaitu penggunaan metodeyang bervariasi dalam kegiatan mengajar akan lebih baik dari padapenggunaan satu metodemengajar. Namun penggunaan satu metode tidaklah salah selama apayangdilakukan itu untuk mencapai tujuan pengajaran secara efektif dan efisien.

Metode pemberian tugassebagai salah satu metodeyangdikaji penulis dalam pembahasan initentunyajugamemilikikelemahandan kelebihan seperti halnyadengan metodeyanglain. Mengenai kelebihan metode pemberian tugasadalah sebagai berikut:

1. Baik sekaliuntuk mengisi waktu luangdengan hal-halyangkonstruktif.

2. Memupuk rasatanggung jawab dalam segala tugaspekerjaan, 
sebabdalam metodeinianak harus mempertanggungjawabkansegala sesuatu(tugas) yangtelah dikerjakan.

3. Memberi kebiasaan anakuntuk belajar.

4. Memberi tugas anakyangbersifat praktis.

Dari berbagai kelebihan-kelebihanyangtelah dipaparkan diatas tentunya metodepemberian tugasjugatidak terlepas dari kelemahan-kelemahan sebagai berikut :

1. Seringkalitugas di rumah itu dikerjakan oleh oranglain, sehinggaanak tidak tahu menahu tentangpekerjaan itu, berarti tujuan pengajaran tidak tercapai.

2. Sulit untuk memberikan tugas karenaperbedaan individual anak dalam kemampuan dan minat belajar.

3. Seringkalianak-anak tidak mengerjakan tugas dengan baik, cukup hanya menyalin pekerjaan temannya.

4. Apabilatugas itu terlalubanyak, akan mengganggu keseimbangan mental anak.

\section{METODOLOGI PENELITIAN}

Penelitian ini menggunakan perencanaan Metode Tindakan Kelas (PTK) yang di kategorikan penelitian yang berusaha untuk memecahkan atau menjawab permasalahan yang dihadapi pada situasi tertentu.

Menurut Kemmis dan Mc Taggart (dalam kunandar 2012:42-43), Penelitian tindakan adalah sebagai bentuk self-inquiri koleksi yang dilakukan oleh partisipasi dalam situasi sosial untuk meningkatkan rasional dan keadilan dari praktek sosial atau pendidik yang mereka lakukan, serta mempertinggi pemahaman mereka terhadap praktekan. Penelitian menggunakan model siklus yang dilakukan secara berulangulang dan kelanjutan, sementara itu dilakukan PTK diantaranya untuk meningkatkan kualitas pendidikan atau pengajaran yang di selenggarakan oleh pendidik/pengajar - peneliti itu sendiri, yang dampaknya diharapkan tidak ada lagi permasalahan yang mengganjal di kelas.

\section{Subjek Penelitian}

Menurut Sanapiah Faisal (2007 : 109) Subjek Penelitian menunjukan pada orang/individu atau kelompok yang dijadikan unit atau satuan (kasus) yang diteliti.

Penelitian ini dilakukan di SDN-1 Pulau Telo dimana subjek penelitian adalah peserta didik kelas V Tahun Pelajaran 2016/2017 yang berjumlah 22 orang.

\section{Teknik Analisis Data}

Data yang dikumpulkan dari setiap siklus akan dianalisis menggunakan metode Mixed Menthods atau metode kombinasi antar kualitatif dan kuantitatif. Creswell ( Sugiyono,2013) menyatakan bahwa"Metode penelitian kombinasi (Mixed Menthods) akan berguna bila metode kuantitatif atau metode kualitatif secara sendiri-sendiri tidak cukup akurat digunakan untuk memahami permasalahan penelitian atau dengan menggunakan metode kualitatif secara kombinasi akan dapat memperoleh pemahaman yang paling baik sehingga 
diperoleh data yang lebih komprehensif, valid, reliable dan obyektif. (bila dibanding dengan satu metode)".

Data yang dikumpulkan dan diolah sedemikian rupa sehingga hasilnya dijadikan bahan untuk analisis. Data dalam penelitian ini memberikan gambaran mengenai hasil belajar dan keaktifan peserta didik dalam pembelajaran IPS dengan penggunaan metode Pemberian tugas. Data yang dikumpulkan dari setiap kegiatan yang dilaksanakan dalam siklus PTK dianalisis secara deskriptif dengan menggunakan teknik persentase untuk melihat kecenderungan yang terjadi dalam pembelajaran.

Data yang diperoleh melalui instrument yang telah dikumpulkan sebelumnya diolah menjadi dua jenis dan data yaitu secara kuantitatif dan kualitatif.

\section{Data Kualitatif}

Pengertian kualitatif merupakan metode- metode untuk mengekplorasikan dan memahami makna diperoleh sejumlah individu atau sekelompok orang dan dianggap berasal dari masalah sosial atau kemanusiaan. Proses penelitian kualitatif ini melibatkan upaya-upaya penting, seperti mengajukan pertanyaan-pertanyaan, dan prosedur-prosedur, mengumpulkan data yang spesifik dari para partisipan, menganalisis data secara induktif mulai dari tema-tema yang khusus ke tema-tema umum, dan menafsirkan makna data. Laporan akhir untuk penelitian ini memiliki struktur atau kerangka yang fleksibel (diadaptasi dari Creswell,2007).
Data kualitatif diperoleh dari lembar observasi yang dimaksudkan untuk mengetahui kelebihan dan kekurangan pembelajaran yang dilakukan. Data kualitatif diperoleh dari aktifitas peserta didik berdasarkan aktifitas yang ingin diamati untuk mengetahui keefektifan pembelajaran menggunakan Metode Pemberian Tugas. Sugiono (Afrida Ulfa 2013:62) menyatakan hasil perolehan skor dari observasi kemudian dijumlah dan diubah ke dalam bentuk persentase.

\section{Kuantitatif}

Penelitian Kuantitatif merupakan metode-metode untuk menguji teori-teori tertentu dengan cara meneliti hubungan antar variabel. Variabel-variabel ini diukur biasanya dengan instrumen-instrumen penelitian, sehingga data yang terdiri dari angka-angka dapat dianalisis berdasarkan prosedur-prosedur statistik. Laporan akhir untuk penelitian ini pada umumnya memiliki struktur yang ketat dan konsisten mulai dari pendahuluan, tinjauan pustaka, landasan teori, metode penelitian, hasil penelitian, dan pembahasan (Creswell, 2008).

\section{DESKRIPSI \\ DATA \\ DAN PEMBAHASAN}

\section{A. Deskripsi Data}

Penelitian PTK memiliki tahapan proses pembelajaran. Banyaknya tahapan pembelajaran yang ingin diperoleh tergantung dari tujuan yang ingin dicapai oleh peneliti. Jenis data tersebut adalah (1) data pratindakan, (2) data siklus I, dan (3) 
data siklus II. Data pratindakan adalah hasil observasi awal hasil tes awal sebelum tindakan kelas dilakukan. Data siklus I adalah data yang diperoleh dari hasil kegiatan tindakan siklus I dan data siklus II diperoleh apabila siklus I belum mencapai criteria ketuntasan maksimum.

Peneliti dan guru kelas $\mathrm{V}$ berdiskusi mengenai rencana penelitian yang akan dilaksanakan, peneliti juga meminta kesediaan untuk membantu menjadi pengamat atau observer pada proses pembelajaran dan peneliti juga menyampaikan bahwa akan melaksanakan kegiatan pembelajaran pada hari Selasa, 27 April 2017 pukul 09.30-10.10 WIB.

Sebelum melakukan penelitian, peneliti terlebih dahulu melakukan uji coba instrument pada kelas V SDN- 1 Pulau Telo dengan jumlah peserta didik 22 orang yang dilaksanakan tanggal 20 April 2017 pukul 09.30-10.10 WIB.

Pembelajaran IPS dengan menggunakan metode ceramah tanpa menggunakan media untuk pengambilan data awal, sedangkan pembelajaran dengan menggunakan metode Pemberian tugas yang digunakan untuk mengetahui adanya peningkatan hasil belajar peserta didik yang meliputi beberapa tahap diantaranya perencanaan, pelaksanaan, pengumpulan hasil penelitian (observasi dan tes hasilbelajar), dan refleksi. Oleh karena itu hasil penelitian difokuskan pada hasil pemantauan terhadap pelaksanaan tindakan sebagai berikut.

\section{Deskripsi Data Pra Tindakan}

Data pra tindakan terdiri atas data awal yang hasilnya diperoleh dari hasil observer pratindakan dan tes pratindakan. Hasil yang diperoleh dari kedua data ini akan dijadikan sebagai tolak ukur keberhasilan pembelajaran selanjutnya. Kedua data tersebut disajikan sebagai berikut:

\section{a. Deskripsi Data Observasi Pra Tindakan}

Hasil pengamatan yang dilakukan oleh peneliti ketika guru kelas melakukan kegiatan pembelajaran dengan materi mengenal tokoh-tokoh pada masa kemerdekaan yaitu sebagai berikut.

1) Masih banyak peserta didik yang kurang aktif bertanya dalam proses pembelajaran.

2) Minat peserta didik dalam mengemukakan pendapat masih rendah

3) Hasil belajar IPS peserta didik khususnya dalam pembelajaran mengenal tokoh-tokoh pada masa kemerdekaan masih mendapatkan nilai dibawah KKM.

4) Kemampuan untuk mengenal tokohtokoh pada masa kemerdekaan masih kurang

5) Peserta didik kurang aktif pada saat proses pembelajaran berlangsung.

\section{Deskripsi Data Tes Pra Tindakan}

Tes pra tindakan bertujuan untuk mengetahui tingkat penguasaan peserta didik dalam materi yang akan dijadikan topik pembelajaran sebelum penelitian tindakan kelas dilaksanakan. Kegiatan dimulai 
dengan peneliti melakukan kegiatan proses pembelajaran terlebih dahulu menggunakan metode ceramah. Kemudian peneliti membagi LKPD (Lembar Kerja Peserta Didik) untuk mengetes kemampuan peserta didik tentang materi yang diajarkan. Peneliti memberikan penjelasan tentang cara mengerjakan dan peneliti berkeliling kelas untuk mengawasi peserta didik mengerjakan soal yang diberikan. Setelah selesai, pendidik meminta peserta didik untuk mengumpulkan hasil pekerjaan mereka.

\section{B. Pengujian Hipotesis Tindakan}

Berdasarkan hipotesis yang telah ditetapkan dalam bab sebelumnya, maka hipotesis tindakan tersebut akan teruji kebenaranya sebagai berikut:

Rumusan hipotesis :

1. Aktivitas belajar IPS dengan menggunakan Metode Pemberian tugas dan media kartu tebak kata lebih baik.

Dalam pengujian hipotesis tindakan terhadap aktivitas belajar peserta didik digunakan untuk mengetahui kebenaran dalam peningkatan aktivitas belajar peserta didik.

Berdasarkan hasil pengamatan data yang diperoleh data yang diperoleh pada siklus I, aktivitas peserta didik memperoleh skor rata-rata 3,04 dengan cukup baik. Pada siklus II, skor rata-rata 3,7 dengan kriteria baik. Hal itu telah mencapai indikator keberhasilan yang telah ditetapkan dan menunjukkan bahwa peserta didik kelas $\mathrm{V}$ SDN 1 Pulau telo Kuala kapuas lebih baik pada saat proses pembelajaran IPS pada Metode pemb erian Tugas dan Media tebak kata maka hipotesis tindakan teruji kebenarannya.

2. Ada peningkatan hasil belajar IPS dengan menggunakan Metode Pemberian Tugas dan media tebak kata di SDN 1 Pulau Telo Kuala Kapuas.

Berdasarkan hasil tes dan data yang diperoleh data tes awal, hasil belajar peserta didik memperoleh nilai rata-rata 44 (di bawah $\mathrm{KKM} \geq 60$ ) dengan ketuntasan klasikal 25\%. Pada siklus I hasil belajar peserta didik memperoleh nilai rata-rata 63,25 dengan ketuntasan klasikal 60\%. Pada siklus II hasil belajar peserta didik memperoleh nilai rata-rata 70 dengan ketuntasan klasikal 100\%. Hal tersebut telah mencapai indikator keberhasilan penelitian yang telah ditetapkan yaitu hasil belajar peserta didik mencapai (KKM $\geq 60$ ) dengan ketuntasan klasikal $85 \%$. Sehingga hal itu menunjukkan bahwa ada peningkatan hasil belajar IPS peserta didik kelas V SDN 1 Pulau Telo dengan menggunakan Metode pemberian tugas dan media tebak kata, maka hipotesis tindakan teruji kebenarnya.

\section{Pembahasan Hasil Penelitian}

a. Pembahasan hasil penelitian dalam pengelolaan data hasil observasi aktivitas guru dan peserta didik. Hasil observasi terhadap aktivitas guru dan peserta didik dalam pembelajaran IPS pada materi jenisjenis pekerjaan adalah sebagai berrikut: Pembahasan dari Pretest 
1) Rata-rata yang diperoleh peserta didik sebesar 44.

2) Peserta didk yang mendapat nilai 60 atau 65 keatas sebanyak 1 orang peserta didik.

3) Peserta didik yang mendapatkan nilai kurang dari 60 sebanyak 15 orang peserta didik.

4) Peserta didik yang telah dinyatakan memiliki ketuntasan belajar $(85 \%)$ sebanyak 5 orang $(25 \%)$ dari jumlah 20 orang peserta didik sedangkan peserta didik yang belum tuntas sebanyak 15 orang.

b. Pembahasan dari Siklus I

1) Rata-rata yang diperoleh peserta didik sebesar 63,25.

2) Peserta didik yang mendapat nilai kurang dari 60 atau 65 keatas sebanyak 5 orang peserta didik.

3) Peserta didik yang mendapat nilai kurang dari 60 sebanyak 7 orang peserta didik.

4) Peserta didik yang telah dinyatakan memiliki ketuntasan belajar $(85 \%)$ sebanyak 12 orang $(60 \%)$ dari jumlah 20 orang peserta didik sedangkan peserta didik yang belum tuntas sebanyak 8 orang $(40 \%)$.

5) Guru belum bisa mengkoordinir kelas sehingga masih ada yang rebut dan ada yang sebagian mengganggu teman dalam kelas.

c. Pembahasan dari siklus II

1) Rata-rata yang diperoleh peserta didik sebesar 70.

2) Peserta didik yang mendapat nilai 60 atau 65 ke atas sebanyak 6 orang peserta didik.
3) Peserta didik yang dinyatakan ketuntasan belajar (85\%) sebanyak 20 orang $(100 \%)$ dari jumlah 20 orang peserta didik sedangkan peserta didik yang elum tuntas tidak ada.

4) Perlu ditingkatkan lagi pengawasan serta cara mengkondisikan kelas sehingga peserta didik focus selama pembelajaran berlangsung.

1. Pembahasan Hasil Analisis Data

Setelah melakukan dan menyelesaikan proses pembelajaran IPS dengan menggunakan media tebak kata nampak bahwa hasil ketuntasan klasikal dari nilai pretest sebelum proses pembelajaran IPS dengan menggunakan media tebak kata berupa tebak kartu dapat dilihat dari nilainilai rata-rata kelas memang kurang baik yaitu dapat dilihat bahwa rata-rata nilainya 44 dan ketuntasan klasikalnya hanya $25 \%$ dan rata-rata nilai setelah di berikan penjelasan pembelajaran IPS dengan menggunakan media tebak kata pada siklus I mencapai rata-rata 63,25 dan ketuntasan klasikal $60 \%$. Pada siklus II nilai rata-rata peserta didik lebih meningkat dari sebelumnya yaitu 70 dan ketuntasan klasikal $100 \%$. Hal ini bahwa dari ketuntasan belajar dinyatakan sudah tuntas.

Disini dapat dilihat bahwa dengan adanya pembelajaran IPS dengan menggunakan media tebak kata berupa tebak kartu ternyata telah memacu peserta didik untuk memperbaiki aktivitas belajar, lebih menarik dan mudah untuk dipahami penjelasan dari guru, sehingga dampaknya pada hasil belajar peserta didik meningkat dari sebelumnya, sedangkan untuk aktivitas 
belajar baik dari guru maupun peserta didik juga terjadi peningkatan dari siklus I untuk guru diperoleh skor rata-rata 3,4 dan peserta didik diperoleh skor rata-rata 3,0, sedangkan pada siklus II untuk kegiatan guru diperoleh skor rata-rata 3,8 dan peserta didik diperoleh skor rata-rata 3,7

Hal ini bahwa penerapan menggunakan media tebak kata di kelas $\mathrm{V}$ SDN 1 Pulau Telo Tahun Pelajaran 2016/2017 dapat meningkat hasil belajar dan aktivitas belajar peserta didik. Jadi dengan demikian sudah terbukti bahwa dengan menerapka media tebak kata pada kelas $\mathrm{V}$ di SDN 1 Pulau Telo, penggunaan media ini dapat meningkatkan hasil belajar peserta didik, peserta didik lebih aktif dalam kegiatan pembelajaran dan meningkatkan pemahaman peserta didik

\section{SIMPULAN}

1. Aktivitas belajar peserta didik kelas V SDN 1 Pulau Telo Kuala Kapuas dengan menggunakan Metode Pemberian Tugas dan media tebak kata menjadi baik. Hal ini dibuktikan dari hasil rata-rata aktivitas pada data hasil observasi peserta didik pada siklus I peserta didik memperoleh skor rata-rata 3,0 dengan kriteria cukup baik. Kemudian pada siklus II meningkat dengan skor rata-rata 3,7 kriteria baik.

2. Ada peningkatan hasil belajar IPA dengan menggunkan Metode pemberian tugas dan media tebak kata pada peserta didik kelas V SDN 1 Pulau Telo Kuala Kapuasa. Ini terlihat dari nilai rata-rata hasil belajar peserta didik saat pra tindakan yaitu 44 dan ketuntasan klasikal
23\% dengan kategori tidak tercapai. Adapun nilai rata-rata pada siklus I adalah 63dan ketuntasan klasikal 60\% dengan kategori tidak tercapai. Pada siklus II adalah 70 dan ketuntasan klasikal 100\% dengan kategori tercapai.

\section{DAFTAR PUSTAKA}

Hamalik O, 2005. Perencanaan Pembelajaran Berdasarkan Pendekatan Sistem, Jakarta : PT Bumi Aksara.

Hasbullah, (2006), Dasar-dasar Ilmu Pendidikan, Jakarta: PT Raja Grafindo Persada

Kunandar. 2012. Langkah Mudah Penelitian Tindakan Kelas sebagai. Pengembangan Profesi Guru. Jakarta: PT Rajawali Press.

Nasution, 2004. Didaktik Asas-asas Mengajar. Jakarta : Rineka Cipta.

Sapriya, 2009. Pendidikan IPS. Bandung: PT Remaja Rosda Karya.

Slameto. 2003. Belajar dan Faktor-faktor yang Mempengaruhinya. Jakarta: Rineka Cipta.

Sudjana,Nana. 2006. Penilaian Hasil Proses Belajar Mengajar. Bandung: PT Remaja Rosdakarya

Sudjana dan Rifai, 2002, Media Pembelajaran, Bandung : Sinar Baru Algensindo. 
Pedagogik Jurnal Pendidikan, Oktober 2017, Volume 12 No 2 (14-27)

Sugiyono, 2009. Metode Penelitian Kualitatif, dan R\&D. Bandung: Pendidikan, Pendekatan Kuantitatif, Alfabeta. 